\title{
Вибір способу біліарної декомпресії у хворих на обтураційну жовтяницю непухлинного генезу
}

\begin{abstract}
Мета роботи: вивчити ефективність біліарної декомпресії після зовнішнього, внутрішнього дренування жовчних проток, ендоскопічних транспапілярних втручань у хворих на обтураційну жовтяницю непухлинного генезу.

Матеріали і методи. Проаналізовано результати хірургічного лікування 200 хворих на обтураційну жовтяницю доброякісного генезу. Хворі були розподілені на три групи: I група ( $=95)$ - застосовували ендоскопічні способи біліарної декомпресії, II група (n = 48) - сформовано біліодигестивні анастомози, III група ( $=57)$ - проводили зовнішнє дренування жовчних проток. Результати досліджень та їх обговорення. У І групі хворих спостерігалось поступове зниження рівня білірубіну та лужної фосфатази і досягнення нормального рівня на 7 добу. У ІІ групі нормалізацію білірубіну і лужної фосфатази відмічено на 14 добу. У ІІІ групі було швидке зниження рівня білірубіну та лужної фосфатази та їхньої нормалізації на 28 добу. Рівень трансаміназ досягав норми раніше у кожній групі хворих.
\end{abstract}

Ключові слова: обтураційна жовтяниця; зовнішнє дренування жовчних проток; біліодигестивні анастомози; ендоскопічні транспапілярні втручання.

Постановка проблеми і аналіз останніх досліджень та публікацій. Обтураційна жовтяниця (ОЖ) - одне $з$ найпоширеніших захворювань органів травлення, яке за даними ВООЗ спостерігається у 10-15 \% населення світу [1, 2]. Доброякісний генез ОЖ зумовлений холедохолітіазом, стенозуючим папілітом, хронічним фіброзним панкреатитом, стриктурами жовчних проток та ін. На сьогодні дискусійним залишається питання стосовно вибору способу біліарної декомпресії. У більшості клінік перевагу віддають двохетапному лікуванню. В міру накопичення досвіду і при вдосконаленні хірургічної техніки все частіше застосовують одноетапну тактику лікування $[3,4,5]$. Однак як одноетапні, так і двохетапні способи декомпресії жовчних проток приводять до прогресування печінкової недостатності після відновлення пасажу жовчі та у 7-42 \% хворих є причиною летальних наслідків [6].

Мета роботи: вивчити ефективність біліарної декомпресії після зовнішнього, внутрішнього дренування жовчних проток, ендоскопічних транспапілярних втручань у хворих на обтураційну жовтяницю непухлинного генезу.

Матеріали і методи. У період 2002-2019 рр. у хірургічній клініці медичного факультету № 2 ВНМУ ім. М. І. Пирогова проходили лікування 200 хворих на ОЖ доброякісного генезу. Жінок було 120 (60,0 \%), чоловіків - 80 (40,0 \%). Віковий поділ проводили відповідно до рекомендацій ВООЗ. Хворих молодого віку було 15 (7,5 \%), се- реднього - 36 (18,0 \%), похилого - 86 (43,0 \%), старечого - 58 (29,0 \%), довгожителів - 5 (2,5\%). Середній вік - $(62 \pm 6,0)$ року. Тривалість ОЖ до 14 діб діагностовано у 107 (53,5 \%), від 14 до 28 діб - у 69 (34,5 \%), більше 28 діб - у 24 (12,0 \%). Середня тривалість ОЖ - $(20 \pm 3,7)$ доби.

Причинами ОЖ були: холедохолітіаз - у 122 (61,0 \%) хворих, синдром Mirizzi - у 15 (7,5 \%), стриктура спільної жовчної протоки (СЖП) у 7 (3,5 \%), стенозуючий папіліт - у 19 (9,5 \%), хронічний фіброзний панкреатит - у 10 (5,0 \%), кіста головки підшлункової залози - у 5 (2,5%), виразка дванадцятипалої кишки (ДПК) з пенетрацією в гепатодуоденальну зв'язку (ГДЗ) - у 2 (1,0%), післяхолецистектомічний синдром - у 20 (10,0 \%).

До лабораторних індикаторів холестазу відносили: підвищення рівня загального і прямого білірубіну, лужної фосфатази, а також оцінювали показники цитолітичного синдрому: активність аспартатамінотрансферази (АсАТ), аланінамінотрансферази (АлАТ) до проведення оперативного втручання та на 1, 3, 5, 7, 10, 14, 28 доби після декомпресії жовчних проток.

Скринінг-методом діагностики патології жовчного міхура і жовчних проток була трансабдомінальна ультрасонографія (ТУСГ), яка проводилась всім хворим на діагностичному апараті Lodgiq-500 PRO Series GE. У всіх хворих на ОЖ виконували фіброгастродуоденоскопію (ФГДС) за допомогою фіброгастродуоденоскопа Pentax$290 \mathrm{~V}$. Для прямого контрастування жовчних проток здійснювали ендоскопічну ретроградну пан- 
креатохолангіографію (ЕРПХГ) із використанням 30 \% водорозчинного контрасту об'ємом 10-20 мл та 3-5 мл для контрастування головної протоки підшлункової залози. Під час операції проводили інтраопераційну холангіографію (IOXГ) шляхом введення 10-20 мл 30 \% контрасту через міхурову протоку або при пункції жовчних проток. При неможливості канюляції великого сосочка (BC) дванадцятипалої кишки (ДПК) виконували ендоскопічну ультрасонографію (ЕУСГ) на діагностичному апараті Olympus Exera EU M 60. Taкож проводили магнітно-резонансну томографію (MPT) на комп'ютерному томографі Somatom-CR при захворюваннях підшлункової залози.

Результати досліджень та їх обговорення. ТУСГ дала можливість діагностувати розширення жовчних проток та наявність в них конкрементів. Інформативність ТУСГ у діагностиці причин ОЖ склала 128 (64,0 \%). У 20 (10,0 \%) хворих незадовільні результати ТУСГ були зумовлені вираженим метеоризмом - 7 (3,5\%), ожирінням 4 (2,0 \%), наявністю множинних дрібних конкрементів у термінальному відділі СЖП - 5 (2,5 \%), аерохолією - 4 (2,0 \%). У таких випадках застосовано ЕУСГ.

ФГДС здійснювали всім хворим на ОЖ, що дало можливість оцінити форму, розміри ВС ДПК, об'єм і характер жовчі, яка виділялась та визначитись 3 можливістю подальшого виконання ЕРПХГ. ФГДС також застосовували для проведення диференційної діагностики ОЖ між вклиненим конкрементом термінального відділу СЖП і патологією ВС ДПК у 19 (9,5 \%) хворих.

ЕРПХГ виконано у 74 (37,0 \%) випадках, що дало можливість діагностувати холедохолітіаз у 55 (27,5 \%) хворих, стенозуючий папіліт - у 19 (9,5 \%). Виконати ЕРПХГ не вдалось у 30 (15,0 \%) хворих через наявність конкремента в ампулі ВС ДПК у 19 (9,5 \%), парапапілярного дивертикулу в 9 (4,5 \%), після резекції шлунка за Більрот II - у 2 (1,0 \%). При неможливості канюляції ВС ДПК застосовано ЕУСГ.

IОХГ проведено 42 (21,0 \%) хворим шляхом введення контрасту через міхурову протоку в 20 (10,0 \%) та при пункції СЖП - у 12 (6,0 \%) випадках під час виконання відкритої холецистектомії (BXЕ). ІОХГ під час проведення лапароскопічної холецистектомії (ЛХЕ) здійснювали через міхурову протоку в 8 (4,0 \%) хворих. Діагностовано холедохолітіаз у 20 (10,0 \%), синдром Mirizzi - у 15 (7,5 \%), стриктуру СЖП - у 7 (3,5 \%).

МРТ застосовано у 17 (8,5 \%) хворих. При патології підшлункової залози МРТ проведено для діагностики хронічного фіброзного панкреатиту - в 10 (5,0 \%) хворих, кісти головки підшлункової залози - у 5 (2,5 \%) та для діагностики виразки ДПК з пенетрацією в ГДЗ - у 2 (1,0 \%).

Хворі були розподілені на три групи: I група (n = 95) - застосовували ендоскопічні способи біліарної декомпресії, II група (n = 48) - сформовано біліодигестивні анастомози, III група (n = 57) проводили зовнішнє дренування жовчних проток.

У хворих I групи застосовували ендоскопічні способи декомпресії жовчних проток у 95 (47,5 \%) випадках. На першому етапі проведено неповну ЕПСТ (до 10 мм) у 20 (10,0 \%) хворих із холедохолітіазом, що забезпечило самостійне відходження конкрементів діаметром до 10 мм. Також неповну ЕПСТ проведено у 19 $(9,5 \%)$ хворих із стенозуючим папілітом. Повну ЕПСТ (більше 10 мм) виконано у 18 (9,0 \%) випадках, що дало можливість провести літоекстракцію кошиком Дорміа (Olympus FG-22Q, Boston scientific trapezoid RX). При множинних конкрементах застосовували літоестрактори з провідником (Boston scientific trapezoid RX with guidewire РТ2). Після повної ЕПСТ проведено механічну літотрипсію (Olympus BML-201Q) у 12 (6,0 \%) хворих при розмірах конкрементів (10-20 мм). Після чого фрагментовані конкременти видаляли кошиком Дорміа.

Ендобіліарне транспапілярне стентування (діаметр стенту - 7 Fr) проведено для тривалої декомпресії жовчних проток у 3 (1,5 \%) хворих із стриктурою термінального відділу СЖП. При інкрустації стента солями жовчних кислот через 3-4 місяці проводили його заміну. При наявності гнійного холангіту здійснено назобіліарне дренування у 20 (10,0 \%) хворих. Наявність дренажу дала можливість проводити санацію жовчних проток розчинами антисептиків (хлоргексидину біглюконат, декаметоксин) та антибіотиків (цефтріаксон, цефоперазон, левофлоксацин). На другому етапі після ліквідації ОЖ і гнійного холангіту, в середньому через 7-10 діб, виконували ЛХЕ.

У I групі хворих спостерігалось поступове зниження рівня білірубіну та лужної фосфатази на 1, 3, 5 доби і досягнення нормального рівня на 7 добу. Рівень АлАТ та АсАТ знижувався до норми на 5 добу (рис. 1). Після ендоскопічних транспапілярних втручань суттєвих порушень функціонального стану печінки не спостерігали, що є оптимальним у післядекомпресійному періоді.

У хворих II групи проводили внутрішнє дренування жовчних проток у 48 (24,0 \%) випадках. При непрохідості дистальних відділів СЖП сформовано холедоходуоденоанастомоз із застосуванням 


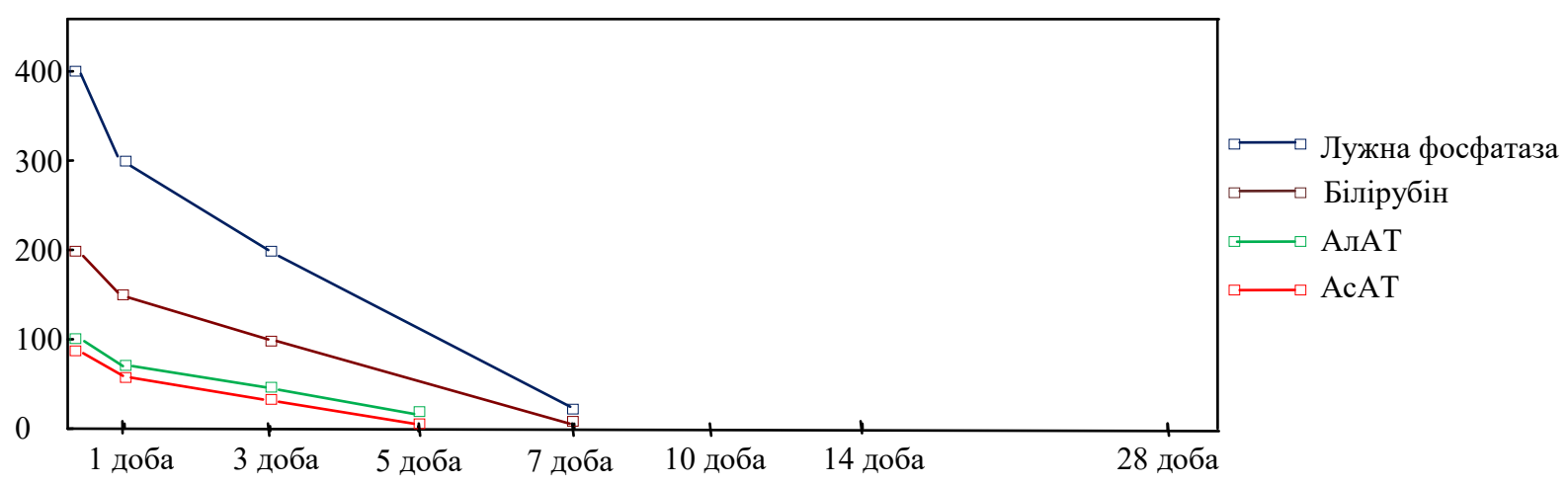

Рис. 1. Рівень білірубіну, лужної фосфатази, АлАТ, АсАТ у хворих I групи.

інтраопераційної техніки попередження рефлюксу дуоденального вмісту (патент України № 85986). Мобілізували супрадуоденальний відділ СЖП та підготовлювали майданчик для анастомозу на низхідній частині ДПК. Здійснювали повздовжню холедохотомію завдовжки 15 мм та дуоденотомію в поперечному напрямку півмісяцевої форми. Формували холедоходуоденоанастомоз за типом “бік у бік” вузловими швами в один ряд крізь всі шари стінок порожнистих органів. При формуванні верхнього краю анастомозу, відступивши 10 мм від дуоденотомного отвору в проксимальному напрямку, в шов захоплювали серозно-м’ язовий шар стінки ДПК. При затягуванні вузла, півмісяцевий клапоть інвагінується у порожнину ДПК, формуючи щілиноподібний клапан, який попереджував дуоденобіліарний рефлюкс та швидку декомпресію жовчних проток після операції. Арефлюксну холедоходуоденостомію застосовано в 38 (19,0 \%) хворих: у 23 (11,5 \%) - $з$ холедохолітіазом поєднаним із стенозуючим папілітом, у 10 (5,0 \%) - із хронічним фіброзним панкреатитом, у 5 (2,5 \%) із кістою головки підшлункової залози.

Комбінованийарефлюкснийгепатикоєюнодуоанастомоз (патент України № 112735) сформовано у 10 (5,0 \%) хворих: із стриктурою СЖП - у 4 (2,0 \%) і з синдромом Mirizzi II типу - в 6 (3,0 \%). Створювали арефлюксний гепатикоєюноанастомоз за типом “бік у бік”. Відступивши на 3-4 см від заглушеного кінця тонкої кишки, прошивали і підтягували вгору передню стінку порожньої кишки, щоб утворився конус. Під лігатурою висікали стінку кишки і розширювали точковий отвір за допомогою затискача в поперечному напрямку. Далі проводили повздовжню гепатикотомію та формували анастомоз між спільною печінковою протокою і порожньою кишкою однорядним вузловим швом, діаметром 15-20 мм з адаптацією слизових оболонок анастомозуючих органів. При проходженні перистальтичної хвилі стінка кишки “змикається”, що перешкоджає рефлюксу кишкового вмісту в жовчні протоки та запобігає швидкій біліарній декомпресії. Відновлювали неперервність кишкової трубки шляхом накладання дворядного міжкишкового анастомозу за типом “кінець у бік” на 30-40 см від попередньо сформованого біліодигестивного анастомозу. Для попередження утворення пептичних виразок і профілактики дуоденостазу формували додатковий дуоденоєюноанастомоз за типом “бік у бік” між виключеним сегментом порожньої кишки і низхідною гілкою ДПК.

Для запобігання жовчовитікання у черевну порожнину $з$ лінії сформованого біліодигестивного анастомозу застосовували У-подібний дренаж (патент України № 101302). Дренажну трубку виводили на передню черевну стінку через контрапертуру та під’єднували до постійного відсмоктувача (5-10 см вод. ст.). Застосування вакуумного пристрою сприяло запобіганню жовчовитікання в черевну порожнину.

У II групі хворих спостерігали зниження білірубіну і лужної фосфатази на 1 добу, поступове підвищення даних показників на 3, 5, 7 доби та їх нормалізацію на 14 добу. Активність АлАТ відновилась на 10 добу, АсАТ - на добу раніше (рис. 2). Формування арефлюксного холедоходуоденоанастомозу і комбінованого арефлюксного гепатикоєюнодуоанастомозу супроводжувалось помірним темпом декомпресії жовчних проток через наявність клапанного механізму.

У хворих III групи проводили зовнішнє дренування жовчних проток у 57 (28,5 \%) випадках. ЛХЕ $з$ цистиколітотомією балонним катетером Фогарті здійснено у 10 (5,0%) хворих за наявності конкрементів до 5 мм. ЛХЕ зі зовнішнім дренуванням СЖП виконано у 8 (4,0 \%) хворих із синдромом Міріззі I типу. 


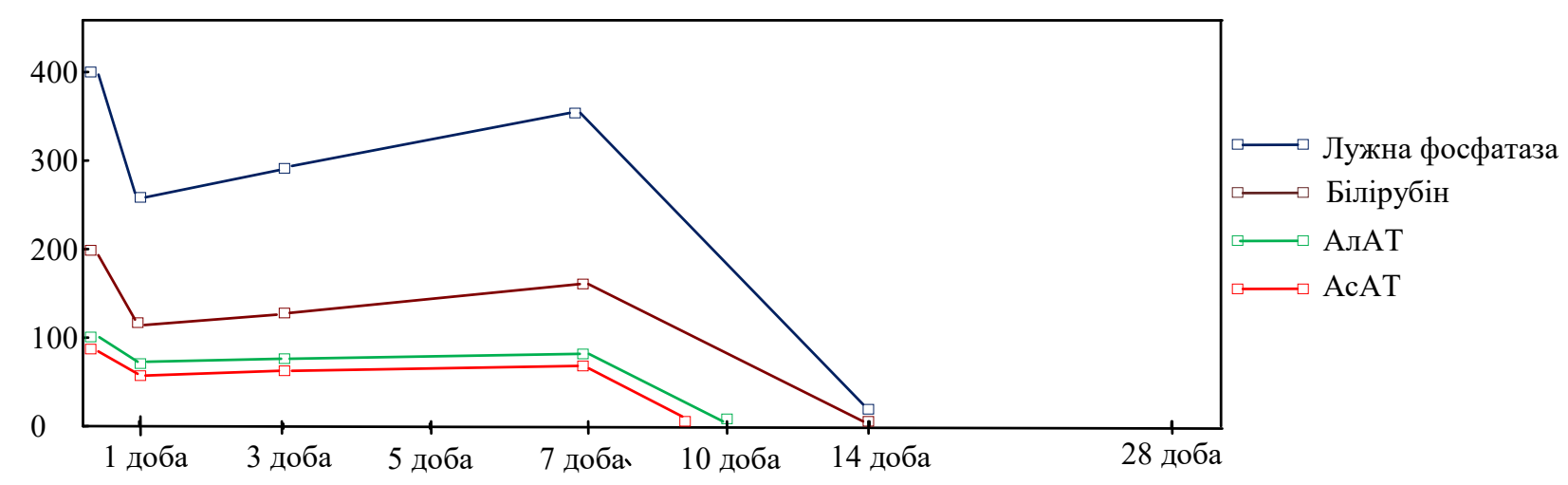

Рис. 2. Рівень білірубіну, лужної фосфатази, АлАТ, АсАТ у хворих II групи.

ВХЕ $з$ холедохолітотомією проведено у 26 $(13,0 \%)$ хворих за наявності конкрементів більше 20 мм, які не вдалось видалити транспапілярно. У 20 (10,0 \%) випадках застосовано зонд-обтуратор позапечінкових жовчних проток (патент України № 104826). В післяопераційному періоді поступово зменшували об'єм балона-обтуратора протягом 7-10 діб, що дало можливість проводити дозовану декомпресію жовчних проток та попередити постдекомпресійну дисфункцію печінки. У 2 (1,0 \%) хворих із пенетруючою виразкою ДПК у ГДЗ виконано розділення виразкового дефекту. Після чого у СЖП утворився дефект протяжністю до 1/3 окружності протоки. Для попередження формування стриктури СЖП після ушивання дефекту протоки застосовували Т-подібний дренаж- балон (патент України № 104469). Балонну дилатацію проводили на рівні пластики СЖП протягом 3 місяців. Через два роки після операції ознак стриктури СЖП не було.

У III групі хворих було швидке зниження рівня білірубіну і лужної фосфатази на першу добу, поступове їх підвищення на 3, 5, 7 доби, зниження на 10, 14 доби і нормалізація на 28 добу. Рівень трансаміназ (АлАТ, АсАТ) досяг норми раніше на 23 і 21 добу відповідно (рис. 3). Виконання зовнішньої декомпресії біліарної системи супроводжувалось швидким зниженням тиску в жовчних протоках, що призводило до післядекомпресійної дисфункції печінки і потребувало проведення дозованої декомпресії жовчних проток протягом 7-10 діб та відповідної медикаментозної терапії.

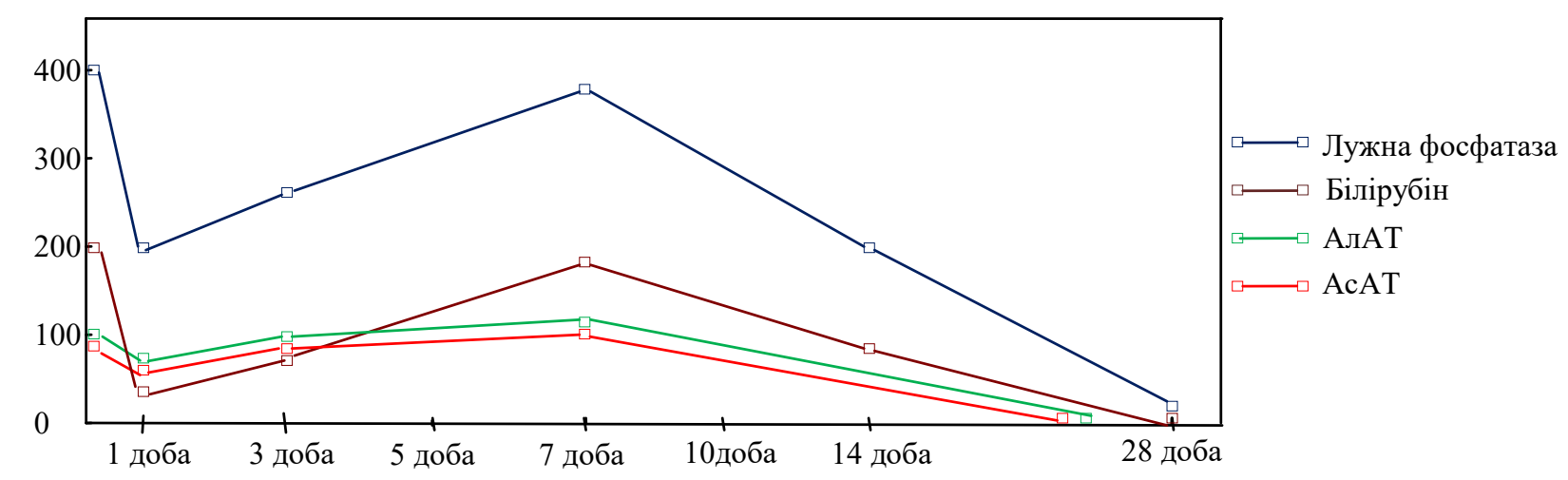

Рис. 3. Рівень білірубіну, лужної фосфатази, АлАТ, АсАТ у хворих III групи.

Висновки. 1. Після ендоскопічних транспапілярних втручань суттєвих порушень функціонального стану печінки не спостерігалось.

2. Формування арефлюксних біліодигестивних анастомозів супроводжувалось помірним темпом декомпресії жовчних проток через наявність клапанного механізму.
3. Виконання зовнішнього дренування жовчних проток характеризується швидким темпом біліарної декомпресії, що призводить до післядекомпресійного синдрому і потребує проведення дозованої декомпресії жовчних проток та відповідної медикаментозної корекції. 


\section{СПИСОК ЛІТЕРАТУРИ}

1. De Palma G. D. Endoscopic snare papillectomy: a single institutional experience of a standardized technique. A retrospective cohort study / G. D. De Palma, G. Luglio, F. Maione // Int. J. Surg. - 2015. - Vol. 13. - P. 180-183.

2. Topal B. Hospital cost categories of one-stage versus twostage management of common bile duct stones / B. Topal, K. Vromman, R. Aerts // Surg. Endosc. - 2010. - Vol. 24. P. 413-416.

3. Costi R. Diagnosis and management of choledocholithiasis in the golden age of imaging, endoscopy and laparoscopy / R. Costi, A. Gnocchi, F. Di Mario // World J. Gastroenterol. - 2014. Vol. 20 (37). - P. 1388-1401.

\section{REFERENCES}

1. De Palma, G. D., Luglio, G., \& Maione, F. (2015). Endoscopic snare papillectomy: a single institutional experience of a standardized technique. A retrospective cohort study. Int. J. Surg., 13, 180-183.

2. Topal, B., Vromman, K., \& Aerts, R. (2010). Hospital cost categories of one-stage versus two-stage management of common bile duct stones. Surg. Endosc., 24, 413-416.

3. Costi, R., Gnocchi, A., \& Di Mario, F. (2014). Diagnosis and management of choledocholithiasis in the golden age of imaging, endoscopy and laparoscopy. World J. Gastroenterol., 20 (37), 1388-1401.
4. Santo M. A. Common bile duct stones: analysis of the videolaparoscopis surgical treatment / M. A Santo, C. E. Domene, D. Riccioppo // Arg. Gastroenterol. - 2012. - Vol. 49 (1). - P. 41-51. 5. Stark A. Endoscopic and operative palliation strategies for pancreatic ductal adenocarcinoma / A. Stark, O. J. Hines // Semin. Oncol. - 2015. - Vol. 42 (1). - P. 163-176.

6. Yang M. J. Partially covered versus uncovered selfexpandable nitinol stents with anti-migration properties for the palliation of malignant distal biliary obstruction: A randomized controlled trial / M. J. Yang, J. H. Kim, B. M. Yoo // Scand. J. Gastroenterol. - 2015. - Vol. 50 (12). - P. 1490-1499.
4. Santo, M.A., Domene, C.E., Riccioppo, D. (2012). Common bile duct stones: analysis of the videolaparoscopis surgical treatment. Arg. Gastroenterol., 49 (1), 41-51.

5. Stark, A., \& Hines, O.J. (2015). Endoscopic and operative palliation strategies for pancreatic ductal adenocarcinoma. Semin. Oncol., 42 (1), 163-176.

6. Yang, M.J., Kim, J.H., \& Yoo, B.M. (2015). Partially covered versus uncovered self-expandable nitinol stents with anti-migration properties for the palliation of malignant distal biliary obstruction: A randomized controlled trial. Scand. J. Gastroenterol., 50 (12), 1490-1499.

\section{O. Y. KANIKOVSKYI, Y. V. KARYI, O. I. BONDARCHUK, S. I. ANDROSOV, AL-MUTASAM BILLAH AL KTAVNEH}

M. Pyrohov Vinnytsia National Medical University

\section{SELECTION OF BILIARY DECOMPRESSION METHOD IN PATIENTS WITH OBSTRUCTIVE JAUNDICE OF NON-TUMOR GENESIS}

The aim of the work: to study efficiency of biliary decompression after external and internal drainage of bile ducts, endoscopic transpapillary interventions in patients with obstructive jaundice of non-tumor genesis.

Materials and Methods. We analyzed the outcomes of surgical treatment of 200 patients with obstructive jaundice of the non-tumor genesis. The patients were divided into three groups: group I ( $=95)$, where endoscopic methods of biliary decompression were used; group II $(n=48)$, where biliodigestive anastomoses were formed; and group III $(n=57)$, where the external drainage of bile ducts was conducted.

Results and Discussion. The patients of the group I demonstrated a gradual decrease of bilirubin and alkaline phosphatase levels, which reached the normal readings on day 7. The patients of the group II demonstrated normal levels of bilirubin and alkaline phosphatase on day 14. The patients of the group III demonstrated rapid decrease of bilirubin and alkaline phosphatase levels, which reached the normal readings on day 28. The transaminase level in each group of patients had reached the norm earlier.

Key words: obstructive jaundice; external drainage of biliary ducts; biliodigestive anastomosis; endoscopic transpapillary intervention. 


\section{ВЫБОР МЕТОДА БИЛИАРНОЙ ДЕКОМПРЕССИИ У БОЛЬНЫХ С ОБТУРАЦИОННОЙ ЖЕЛТУХОЙ НЕОПУХОЛЕВОГО ГЕНЕЗА}

Цель работы: изучить эффективность билиарной декомпрессии после внешнего, внутреннего дренирования желчных протоков, эндоскопических транспапилярных вмешательств у больных с обтурационной желтухой неопухолевого генеза.

Материалы и методы. Проанализированы результаты хирургического лечения 200 больных с обтурационной желтухой доброкачественного генеза. Больные были разделены на три группы: I группа (n = 95) - применяли эндоскопические способы билиарной декомпрессии, II группа $(\mathrm{n}=48)$ - сформировано билиодигестивные анастомозы, III группа $(\mathrm{n}=57)-$ проводили наружное дренирование желчных протоков.

Результаты исследований и их обсуждение. В I группе больных наблюдалось постепенное снижение уровня билирубина и щелочной фосфатазы и достижения нормального уровня на 7 сутки. Во II группе нормализацию билирубина и щелочной фосфатазы отмечено на 14 сутки. В III группе было быстрое снижение уровня билирубина и щелочной фосфатазы и их нормализация на 28 сутки. Уровень трансаминаз достигал нормы раньше в каждой группе больных.

Ключевые слова: обтурационная желтуха; наружное дренирование желчных протоков; билиодигестивные анастомозы; эндоскопические транспапилярные вмешательства. 